\title{
INTERNATIONAL COMPARATIVE INDICATORS ON TEACHERS
}

\author{
H. W. C. GONNIE VAN AMELSVOORT and JAAP SCHEERENS
}

University of Twente, Faculty of Educational Science and Technology, Department of Educational Administration, PO Box 217, 7500 AE Enschede, The Netherlands

\begin{abstract}
The main objective of this chapter is to discuss the relevance and feasibility of international comparative indicators on teachers. Three rationales for the selection of teacher indicators are described. Data availability and interpretation problems due to lack of standard definitions appear to be important problems in international comparisons. Some illustrative findings on teaching time, teacher education, teacher compensation, and teacher characteristics are presented. Copyright $(\mathcal{C} 1996$ Elsevier Science Lid
\end{abstract}

\section{Introduction}

Investing effort in the development of internationally comparative indicators on teachers could be legitimized from a human resources perspective. In many countries a substantial part of the total labor force is employed in education. Teaching staff represents on average about $3 \%$ of the total labor force in 16 OECD member countries, while the percentage of all staff employed in education in these countries amounts to more than 5\% (Organization for Economic Cooperation and Development [OECD], 1995). The largest single component of the cost of education in any country is teacher compensation. Given the total funds for education, the reported share for compensation of teachers is about $60 \%$ (OECD, 1995).

Improving the quality of education is on the policy agenda of most governments (OECD, 1990; van Amelsvoort, Scheerens, \& Branderhorst, 1995) and teachers are alleged to be the most important enablers of educational improvement. Consequently, the success of educational outcomes will ultimately depend on the work and activities of teachers. However, the teaching profession is confronted with rapidly changing conditions and inherent tensions. Demands and expectations on the teacher force increase while monetary and non-monetary compensation decreases. At present, it is widely claimed that the teaching profession is demoralized and suffering from diminished job satisfaction and decreased commitment, a situation that might not only affect the quality of teaching but even the adequacy of teacher supply in the long term. 
In this chapter the selection, definition, measurement, calculation, and interpretation of international teacher indicators are discussed. Three rationales are initially described from which indicators on teachers can be generated: macro-level descriptions, political economy, and effectiveness and efficiency. Next, international comparability problems concerning standard definitions and data availability are examined. Some illustrative findings, based upon the 1994 and 1995 rounds of data collection for the OECD Indicators of Education Systems (INES) project and the key data project of the European Union are presented. While the theoretical part of the chapter deals with a broad spectrum of politically relevant indicators, the emphasis in the empirical part of this chapter is on four indicators that appear to be both politically relevant and feasible: teaching time, teacher education, teacher compensation, and the age and gender distribution of teachers.

\section{Selection of Teacher Indicators}

Prospective teacher indicators can be generated from three kinds of perspectives. From the perspective of macro-level descriptions, estimates of the magnitude of a country's investment in human resources for education and descriptive statistics on characteristics of the teacher force such as age and gender can provide policy-relevant information on problematic aspects (e.g., a "graying" teacher force).

From the perspective of the political economy of the teaching profession, all issues related to the motivation to be and remain a teacher are the focus of attention. Four major categories of system-level conditions that will affect the attractiveness of being a teacher can be distinguished: (a) supply and demand, (b) basic financial conditions, (c) workload, and (d) career opportunities.

From the perspective of efficiency and effectiveness (apart from more traditional input indicators like teacher/pupil ratio and teacher experience), process indicators defined at the school and classroom levels are considered relevant. Examples include instructional time, opportunity to learn, and structured teaching. Further information on these perspectives for selecting teacher indicators is provided in Scheerens (1995).

\section{International Comparability}

A general problem in making international comparisons of system-level data is that several assumptions about general practice have to be made. Furthermore, problems arise when differences between countries with respect to educational aspects are too large to allow for meaningful comparisons. For example comparisons of teacher salaries are difficult in light of the fact that across countries large differences exist in supplementary payments for teachers [e.g., bonuses for teachers in educational priority areas, for participating in school improvement projects, or holiday bonuses and family allowances (Le Métais, 1992)]. Both a review of empirical international studies on teachers and the experiences with the OECD Network $C$ international survey on teachers and curriculum reveal certain problems and likely pitfalls of international comparisons. These problems concern data availability and the use of standard definitions of terms. 


\section{Data Availability}

Data on some teacher indicators in countries of the European Community, namely teacher salaries, teacher working hours, and teacher education, seem to be readily obtainable from national centers for statistics. Experiences with several OECD data collections reveal an emerging availability of data on the gender distribution of teachers, teacher/pupil ratio, unemployment rates, shortages of teachers for certain subject matter areas, and class size. On some prospective indicators, most notably stability of the national teacher force (i.e., data on the flows of teachers and teacher experience), data availability appears to be too low to calculate indicators. Recent attempts have been made to increase data availability on the stability of the teacher force by collecting data at the school level by means of a survey of schools within the framework of the OECD INES project.

Although data are available on topics like working time, salaries, teacher education, and teacher characteristics, it has to be mentioned that they often concern only a small subset of potentially fruitful data categories. Partial information certainly reduces the scope of a particular indicator and, as a consequence, limits the validity and policy relevance of the information. Considering the future, the data situation concerning indicators could be improved not only by countries providing better and more detailed statistics, but also by collecting school-level data on relevant teacher characteristics.

\section{Standard Definitions}

One of the conditions in comparing data from different countries in a reliable way is defining the underlying constructs as explicitly and unequivocally as possible. Nevertheless, interpretation of intcrnational data remains a major problem due to the imperfection of current definitions. These definitions are not always in accordance with those used by central statistics offices in diverse countries and thus not all national statistics are easy to interpret.

Furthermore, teachers are only one segment of those employed in educational institutions. There are two common methods of classifying education personnel - by occupation or by formal qualification. Classifying education personnel by their occupation reflects the present use of human resources in education organizations. Often two general categories of education personnel are distinguished - teaching and non-teaching staff, which can be further grouped into (i) teachers, (ii) other direct education personnel, (iii) indirect support personnel, and (iv) teachers in the work-based component of vocational and technical programs. It is important to note that, generally, personnel indicators cover only teaching personnel, whereas expenditure indicators cover the full cost of education, including indirect support activities. Furthermore, difficulties obtaining data on the numbers of non-teaching staff can be observed in many countries (Ingersoll \& van Amelsvoort, 1995; UOE [UNESCO/OECD/EUROSTAT], 1995).

For the purpose of the 1995 OECD Network C international survey on teachers*, from which some illustrative findings are presented in the next section, a classroom teacher is defined as a person whose professional activity involves the transmission of knowledge, attitudes, and skills that are stipulated to students enrolled in an educational program. This definition does not

\footnotetext{
*OECD has four networks: (A) student outcomes, (B) student destinations, (C) school features and processes, and (D) artitudes and expectations.
} 
depend on the qualification held by the teacher nor on the delivery mechanism. It is based on three concepts: (i) activity, thus excluding teachers without active teaching duties; (ii) profession, thus excluding people who work occasionally or in a voluntary capacity in educational institutions; and (iii) formal program, thus excluding people who provide services other than formal instruction to students (e.g., supervisors, activity organizers) whether the program is established at the national or school level. Principals, presidents, vice-principals and other administrators without teaching responsibilities for students in educational institutions are not classified as teachers. Apprenticeship trainers who guide trainees on the job in a dual system in vocational education are excluded. Also, special education teachers in special schools for students with learning difficulties or mental or physical disabilities are excluded. These definitions are in line with those adopted in the 1995 joint survey of UNESCO, OECD and EUROSTAT, but are to some extent restricted for the specific purposes of the Network $\mathrm{C}$ survey.

Classification of teachers by qualification is useful for examining data on the total teacher force and for forecasting future supply and demand of different qualification levels of teachers. The International Standard Classification of Education (ISCED) discerns seven levels of education, from the level of pre-primary education (ISCED 0) to the second degree university tertiary level of education (ISCED 7). These ISCED levels are being used to provide the basis for classifying teachers and other education personnel by formal qualification. However, due to large differences in education levels and structures of educational training across countries, international comparability of qualification data suffers from many interpretation problems.

\section{Illustrative Findings}

The results of the OECD Network C international survey on teachers in 1994 were used to compute indicators on teaching time, duration of teachers' education, teacher compensation, and teacher characteristics (age and gender). Based on the problems encountered with respect to data availability and interpretation, the instrument was slightly adapted for the 1995 round of data collection. Some illustrative data from the 1995 survey (1993/1994 data) are reported and compared with data from the 1994 survey (1991/1992 data) in cases where comparisons are possible. Comparisons between the 1994 and 1995 data should be made with caution because the definitions of the central concepts needed to be refined, although they have not been changed fundamentally. It should also be noted that the 1995 survey data have not gone through all stages of checking and control required for them to be considered as the basis for publishable OECD indicators. Both surveys covered four ISCED levels (preprimary, primary, lower secondary and upper secondary education). Data availability was the criterion for the selection of the school levels included in the tables. Data were collected through country representatives in Network $C$. The data sources on which the figures are based are explicitly mentioned. For each country the national coordinator of the international indicator project checked the figures. Next to these figures some information on the measurement, calculation, and interpretation of each indicator is given. In addition to the OECD data on teacher education, information on inservice training of teachers is presented.

\section{Teaching Time and Working Time}

Teaching time is one of the most important working conditions of teachers and is related to motivational aspects of the profession. Not only the absolute number of teaching hours, but also 
the proportion of the working time associated with teaching can be interpreted as a measure of the work load of teachers. This proportion provides information about time available for planning and other professional activities. The relationship between working time and teaching time is illustrated in the scheme below.

Working Time

Teaching time

Non-teaching time

Teaching a group or class of students

Teaching related tasks, such as:

- preparation of lessons

- correction of assignments and tests

- meeting about reporting on students

- professional development activities

- annual exams

- work related to diplomas, certifications

- meetings with parents

General school tasks, such as:

- support of students

- cultural activities

- meetings

- organisation/advisory tasks

In the context of the 1995 OECD Network $C$ teacher survey, working time corresponds to the total number of hours a full-time teacher is (formally) paid for according to his/her appointment (excluding overtime that is additionally paid). Teaching time corresponds to the number of hours a full-time appointed teacher is teaching a group or class of students according to the formal policy in a country. Excluded are periods of time formally allowed for breaks between lessons or group of lessons.

Table 7.1 provides information on the number of hours per year a public junior high school teacher teaches a group of students according to the formal policy (school years of reference: 1991/1992 and 1993/1994). Furthermore, some figures about the formal length of the school year are presented.

The average number of teaching hours is 781 in 1991/1992 and 766 in 1993/1994 with a range from 576 hours in Sweden to 1,080 hours in Turkey (1991/1992) and from 569 hours in Greece to 1,056 hours in Switzerland (1993/1994). In 1993/1994 countries were explicitly asked not to count days schools were closed for festivities and celebrations. The 1991/1992 figures may or may not include these closure days. Table 7.1 shows that the length of the school year in terms of teaching weeks per year is shortest in Ireland (33) and longest in Denmark, Germany, and the Netherlands (40). The proportion of teachers' working time devoted to teaching is presented in the far right column and is on average $56 \%$. Countries vary quite substantially with respect to this proportion, which could be interpreted as an indication of the differences in teacher work load. The highest work load can be found in Turkey (92) and Ireland (100), while the lowest work load can be reported for the Scandinavian countries. In Norway and Sweden teachers have to spend only $36 \%$ and $33 \%$ of their working time on teaching, respectively. 
Table 7.1

Teaching Time and Working Time of Teachers (Public Lower Secondary Education; Junior High School)

\begin{tabular}{|c|c|c|c|c|c|}
\hline \multirow[t]{2}{*}{ Country } & \multicolumn{2}{|c|}{ Teaching hours per annum } & \multirow{2}{*}{$\begin{array}{c}\begin{array}{c}\text { Teaching } \\
\text { weeks per } \\
\text { annum }\end{array} \\
1993 / 1994\end{array}$} & \multirow{2}{*}{$\begin{array}{c}\begin{array}{c}\text { Closure days } \\
\text { per annum }\end{array} \\
1993 / 1994\end{array}$} & \multirow{2}{*}{$\begin{array}{c}\text { Teaching time } \\
\text { as a percentage } \\
\text { of working } \\
\text { time } \\
1993 / 1994\end{array}$} \\
\hline & $1991 / 1992$ & $1993 / 1994$ & & & \\
\hline Austria & 747 & 651 & 39 & 10 & 41 \\
\hline Belgium & 720 & 720 & 37 & 5 & - \\
\hline Denmark & & 750 & 40 & & 45 \\
\hline Finland & 798 & & & 0 & \\
\hline France & 632 & 660 & 36 & 3 & - \\
\hline Germany (FTER) & 761 & 712 & 40 & 12 & 42 \\
\hline Greece & & 569 & 36 & 7 & 38 \\
\hline Ireland & 792 & 735 & 33 & 16 & 100 \\
\hline Italy & 612 & 612 & 34 & 4 & 74 \\
\hline Netherlands & 954 & 954 & 40 & 0 & 60 \\
\hline New Zealand & 897 & 869 & 39 & 0 & - \\
\hline Norway & 666 & 611 & 38 & 2 & 36 \\
\hline Portugal & 648 & 681 & 39 & 9 & 46 \\
\hline Spain & 900 & 900 & 36 & 15 & 62 \\
\hline Sweden & 576 & 576 & & & 33 \\
\hline Switzerland & & 1,056 & 39 & 4 & 一 \\
\hline Turkey & 1,080 & 996 & 36 & 14 & 92 \\
\hline United Kingdom & 669 & & & & \\
\hline United States & 1,042 & 964 & 36 & & \\
\hline Country mean & 781 & 766 & 37 & 7 & 56 \\
\hline
\end{tabular}

Note: some countries have no data on official working time.

(Sources: OECD, 1995, 1996.)

\section{Teacher Education}

Teacher qualifications refer to the educational/professional background of teachers. Formal training of teachers is an important factor in maintaining quality standards in education. The duration of initial teacher education is indicative of the skill level of starting teachers. In addition, the importance of continuing education for teachers is becoming fully recognized. Inservice training may be defined as "a variety of activities and practices in which teachers become involved in order to broaden their knowledge, improve their skills, and assess and develop their professional approach" (Perron, 1991 in Eurydice, 1995, p. 8).

The number of years of initial training indicates the total minimum number of years of primary, secondary, and tertiary education (teacher education) required to start working as a fully qualified teacher, according to the formal policy in a country; in systems where the teacher has to work in practice before being qualified - these years of practice have been included. Two types of initial training are commonly distinguished. In the concurrent model, educational theory and practical training courses for teachers are provided at the same time as their general course of study. In the consecutive model, these two aspects of teacher education are provided as a follow-up to the general course. In the member states of the European Union the consecutive model is more typical of initial training for secondary education teachers, whereas the concurrent model is mostly adopted in the initial training of (pre)primary teachers (European Commission [EC], 1994). 
Figures on participation of teachers in inservice training are still scarce because countries are not used to keeping statistics in this rather recent field. Besides, only part of the inservice training is centrally arranged (EC, 1994).

Table 7.2 shows that the number of years required to become a qualified primary and lower secondary education teacher is 15-17 years in most countries. Participation rates refer to the percentage of teachers that actually participated in inservice training courses in 1991/1992 or 1992/1993. Although the information on participation in inservice training provides a partial picture - no information is given on the organization or intensity of this training for instance it can be seen that the rates hardly differ between primary and secondary education, except for Luxembourg. In Portugal (50\%) and Spain (42\%) the percentages are relatively high. In these countries career advancement is linked to inservice training (EC, 1994).

Table 7.2

Number of Years of Initial Training (1991/1992) and Percentage of Teachers Participating in Inservice Training (in $1991 / 1992$ or $1992 / 1993$ )

\begin{tabular}{|c|c|c|c|c|}
\hline \multirow[t]{2}{*}{ Country } & \multicolumn{2}{|c|}{ (Public) Primary education } & \multicolumn{2}{|c|}{ (Public) Lower secondary education } \\
\hline & $\begin{array}{l}\text { Number of years } \\
\text { initial training }\end{array}$ & $\begin{array}{c}\text { Participating in } \\
\text { inservice training (\%) }\end{array}$ & $\begin{array}{l}\text { Number of years } \\
\text { initial training }\end{array}$ & $\begin{array}{c}\text { Participating } \\
\text { inservice training (\%) }\end{array}$ \\
\hline Austria & 15 & - & 15 & - \\
\hline Belgium (FR) & 15 & 25 & 15 & - \\
\hline Denmark & & 35 & & 35 \\
\hline Finland & 17 & - & 18 & - \\
\hline France & 16 & - & 16 & - \\
\hline Germany (FTER) & 19 & - & 19 & - \\
\hline Greece & & $15-20$ & & $15-20$ \\
\hline Iceland & & 23 & & 23 \\
\hline Ireland & 16 & - & 17 & - \\
\hline Italy & 13 & - & 17 & - \\
\hline Luxembourg & & 73 & & 28 \\
\hline Netherlands & 17 & 33 & 17 & 33 \\
\hline New Zealand & 17 & & 17 & \\
\hline Norway & 15 & - & 15 & - \\
\hline Portugal & 17 & 44 & 17 & 50 \\
\hline Spain & 15 & 42 & 15 & 42 \\
\hline Sweden & 16 & - & 16 & - \\
\hline Turkey & 15 & - & 15 & - \\
\hline United States & 16 & & 16 & \\
\hline
\end{tabular}

[Sources: OECD; Eurydice, 1995 (inservice figures)]

\section{Teacher Compensation}

This indicator shows the average gross salaries of teachers in public lower secondary education at the middle of their career (i.e., at 15 years of experience). It also provides information about the number of years it takes to grow from minimum to maximum salary. Salaries are converted into purchasing power parity (PPP) rates (at the current price level) in order to make comparisons among countries meaningful. Teacher salaries can be related to the gross domestic product per capita (GDP per capita) to get an idea of the status of the teaching profession in a country. 
Table 7.3

Mid-career Salaries of Teachers in Lower Secondary Public Education [in Equivalent U.S. Dollars Converted Using PPPs (price level 1992; 1994)], GDP Per Capita and Years From Minimum to Maximum Salary

\begin{tabular}{|c|c|c|c|c|c|c|}
\hline \multirow[t]{2}{*}{ Country } & \multicolumn{3}{|c|}{$1991 / 1992$} & \multicolumn{3}{|c|}{$1993 / 1994$} \\
\hline & $\begin{array}{l}\text { GDP per } \\
\text { capita } \\
\text { (1992) }\end{array}$ & $\begin{array}{c}\text { Gross } \\
\text { salary at } \\
15 \text { years of } \\
\text { experience }\end{array}$ & $\begin{array}{l}\text { Years from } \\
\text { minimum } \\
\text { to maximum } \\
\text { salary }\end{array}$ & $\begin{array}{l}\text { GDP per } \\
\text { capita } \\
\text { (1994) }\end{array}$ & $\begin{array}{c}\text { Gross } \\
\text { salary at } \\
15 \text { years of } \\
\text { experience }\end{array}$ & $\begin{array}{c}\text { Years from } \\
\text { minimum } \\
\text { to maximum } \\
\text { salary }\end{array}$ \\
\hline Austria & 18096 & 25497 & 34 & 20210 & 25533 & 34 \\
\hline Belgium & 18195 & 25514 & 27 & 20166 & 27997 & 27 \\
\hline Denmark & — & & - & 20548 & 28096 & 14 \\
\hline Finland & 14545 & 24049 & 20 & 16208 & 22727 & 20 \\
\hline Germany (FTER) & 20435 & 33516 & 22 & 19675 & 36213 & 21 \\
\hline Greece & - & & - & 11315 & 14946 & 32 \\
\hline Ireland & 12391 & 27697 & 24 & 15212 & 34248 & 24 \\
\hline Italy & 17482 & 23864 & 40 & 18681 & 23133 & 40 \\
\hline Netherlands & 17023 & 26712 & 25 & 18589 & 28191 & 25 \\
\hline New Zealand & 14434 & 25631 & 9 & 16248 & 22511 & 8 \\
\hline Norway & 17756 & 21336 & 14 & 21968 & 21806 & 14 \\
\hline Portugal & 9766 & 26529 & 29 & 12335 & 30079 & 29 \\
\hline Spain & 12853 & 25520 & 45 & 13581 & 26955 & 42 \\
\hline Sweden & 16590 & 19698 & 15 & 17422 & 20413 & 20 \\
\hline Switzerland & - & & - & 23942 & 49095 & 21 \\
\hline Turkey & 3728 & 8964 & 29 & 5271 & 7172 & 27 \\
\hline United States & 23215 & 31258 & 16 & 25512 & 29577 & 16 \\
\hline Country mean & 15465 & 24699 & 25 & 17464 & 26394 & 24 \\
\hline
\end{tabular}

(Sources: OECD 1995, 1996.)

Various criteria for salary increments are used. In most countries salary increments are based on seniority. Merit pay is sometimes used as a criterion for salary improvement in Germany, Ireland, Portugal and Turkey (OECD, 1996).

Table 7.3 shows that teacher salaries at 15 years of experience generally have risen from $1991 / 1992$ to $1993 / 1994$ and are above the GDP per capita in all countries. However, the interesting part of interpretation concerns the salary increase relative to increases of the GDP per capita. The mean ratio salary to GDP is $1.6(1991 / 1992)$ and $1.5(1993 / 1994)$ indicating no substantial shifts in teachers' relative standing. The status of Irish, Portuguese, and Turkish teachers is relatively high, as their mid-career salaries are far above GDP per capita in both years. The standing of teachers in 1993/1994 is also relatively high in Switzerland (ratio of salary to GDP $=2.05$ ). Teachers' salaries after 15 years of experience are relatively low in Norway and Sweden.

On average teachers grow from their starting salary to their maximum salary in 25 (1991/1992) and 24 (1993/1994) years. In Sweden the number of required years to reach the maximum salary has grown from 15 to 20 years. In most countries the figures for 1991/1992 do not deviate from the 1993/1994 figures with respect to years required to progress to the maximum salary. 


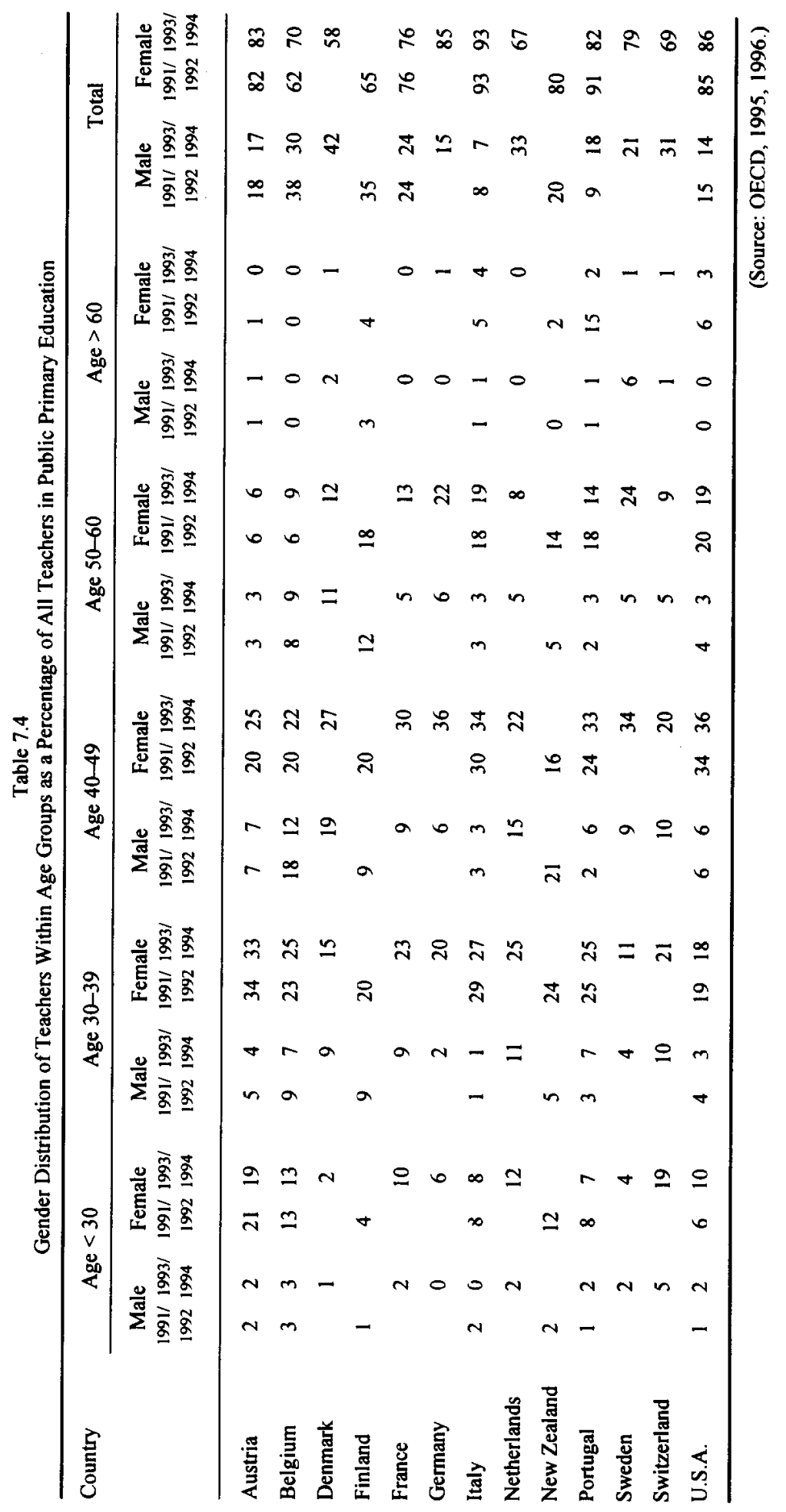




\section{Teacher Characteristics}

Age and gender data can provide insights into the composition of the teacher force. This indicator provides information about the age and gender distribution in percentages of the total teacher force at the level of public primary education.

In public primary education teachers are predominantly female. A relatively high proportion of male teachers can be found in Belgium (38\% in 1991/1992) and Denmark (42\% 1993/1994). For some countries the gender distribution can be compared over the two years. The percentage of male teachers in Portugal has increased while in Belgium it has decreased. Looking at the gender distribution within age groups, the highest proportion of female teachers is between 30 and 49 years of age.

\section{Conclusion}

Only four areas of the potential teacher indicators mentioned in section one could actually be reported. Apparently there are serious deficiencies in the available descriptive statistics on teachers. Hopefully, the efforts of the OECD INES project will gradually improve the data situation with respect to statistics on teachers. Another problem of data availability is that, in order to gain richer information on particular aspects of teacher functioning, one would require data at the school level. This would be relevant for areas such as special training, more precise estimation of the work load, the discretion teachers have in carrying out their jobs, and their experience.

Nevertheless, the information described here by way of illustration can be considered interesting and policy relevant. The data on teacher salaries are probably the most interesting among the set of current indicators. Not only are there substantial differences in the absolute values of mid-career salaries between countries, but the same is true with respect to the number of years it takes to rise from minimum to maximum salary. The extremes are $9(1991 / 1992)$ and 8 (1993/1994) in New Zealand to $45(1991 / 1992)$ and $42(1993 / 1994)$ in Spain. It is also quite interesting to note that in all countries mid-career salaries of junior high school teachers are above the general welfare level. All these factors are relevant with respect to the attractiveness of the teaching profession in a particular country.

Another interesting finding is the fact that, to some extent, the OECD countries studied have an aging teaching population (the age group 40-49 accounting for the largest proportion of the teaching force, with a sizable number aged 50-60). The outcomes with respect to the sex distribution of teachers are less surprising.

The policy relevance of this information rests on the potential for control that all of these conditions have. The international "benchmarks" that for example, data on salaries provide may play a role in national policies in this area.

Comparison of the 1991/1992 and the 1993/1994 figures shows a considerably overall stability. The ratio of teacher salaries to GDP per capita has remained stable, indicating no overall developments in the status of teachers. Nevertheless, in some countries teacher salaries have increased, while in Sweden the number of years from minimum to maximum salary has increased.

\section{References}

Amelsvoort, van H. W. C. H., Scheerens, J., \& Branderhorst, E. M. (1995). Decentralization in education in an international perspective. Enschede: University of Twente. 
European Commission (1994). Key data on education in the european union. Brussels: Author.

Eurydice (1995). Structures of the education and initial training systems. Brussels: Author.

Ingersoll, R., \& Amelsvoort, van H. W. C. H. (1995). Education personnel. Internal draft publication. Enschede: University of Twente.

Le Métais, J. (1992). Teachers' salaries, In H. Tomlinson (Ed.), Performance related pay in education (pp. 22-33). London: Routledge.

Organization for Economic Cooperation and Development [OECD] (1990). The teacher today. Paris: Author.

OECD (1995). Education at a glance 3. OECD indicators. Paris: Author.

OECD (1996, in press). OECD Education indicators. Paris: Author.

Scheerens, J. (Ed.). (1995). Measuring the quality of schools. Paris: Author.

UOE (1995). 1995 Data collection on education statistics (draft). Paris: UECO.

\section{Biographies}

Gonnie van Amelsvoort is Educational Researcher and Lecturer in Educational Management and Organization at the University of Twente. She has participated in the OECD/INES project since 1994. Her research interests include educational evaluation and the monitoring of student progress.

Jaap Scheerens is Professor of Education and Head of the Department of Educational Organization and Management at the University of Twente, the Netherlands. He is also Director of the Centre for Applied Educational Research (OCTO) at the same university. 